\title{
Correction to: Alantolactone, a natural sesquiterpene lactone, has potent antitumor activity against glioblastoma by targeting IKKßkinase activity and interrupting NF-KB/COX-2-mediated signaling cascades
}

Xun Wang ${ }^{1,2}$, Zhenlong Yu ${ }^{1}$, Chao Wang ${ }^{1}$, Wei Cheng ${ }^{1}$, Xiangge Tian ${ }^{1}$, Xiaokui Huo ${ }^{1}$, Yan Wang ${ }^{1}$, Chengpeng Sun', Lei Feng ${ }^{1}$, Jinshan Xing', Yulong Lan', Dongdong Sun ${ }^{1}$, Qingjuan Hou', Baojing Zhang ${ }^{1}$, Xiaochi Ma ${ }^{1 *}$ and Bo Zhang ${ }^{1 *}$

Correction to: J Exp Clin Cancer Res 36, 93 (2017) https://doi.org/10.1186/s13046-017-0563-8

Following publication of the original article [1], the authors identified errors in Fig. 3c and Fig. 7a. The lane protein of $\beta$-actin for U251 cells in Fig. 3c and the IKK $\alpha$ for U87 and IKB $\alpha$ for U251 in Fig. 7a were misuploaded. The correct figures are given below. The authors declare that these corrections do not change our

Published online: 23 September 2020

\section{Reference}

1. Wang X, Yu Z, Wang C, et al. Alantolactone, a natural sesquiterpene lactone, has potent antitumor activity against glioblastoma by targeting IKK $\beta$ kinase activity and interrupting NF-kB/COX-2-mediated signaling cascades. J Exp Clin Cancer Res. 2017;36(1):93. results or conclusions of this article and apologize for any confusion that have caused.

\section{Author details}

'Department of Neurosurgery of the Second Affiliated Hospital, College of Pharmacy, Institute of Cancer Stem Cell, Dalian Medical University, Dalian, China. ${ }^{2}$ Department of Neurosurgery, the Third People's Hospital of Dalian, Non-directly Affiliated Hospital of Dalian Medical University, Dalian, China.

\footnotetext{
The original article can be found online at https://doi.org/10.1186/s13046017-0563-8.

* Correspondence: maxc1978@163.com; Zhangbodl@126.com

'Department of Neurosurgery of the Second Affiliated Hospital, College of

Pharmacy, Institute of Cancer Stem Cell, Dalian Medical University, Dalian,

China

Full list of author information is available at the end of the article
}

(c) The Author(s). 2020 Open Access This article is licensed under a Creative Commons Attribution 4.0 International License, which permits use, sharing, adaptation, distribution and reproduction in any medium or format, as long as you give appropriate credit to the original author(s) and the source, provide a link to the Creative Commons licence, and indicate if changes were made. The images or other third party material in this article are included in the article's Creative Commons licence, unless indicated otherwise in a credit line to the material. If material is not included in the article's Creative Commons licence and your intended use is not permitted by statutory regulation or exceeds the permitted use, you will need to obtain permission directly from the copyright holder. To view a copy of this licence, visit http://creativecommons.org/licenses/by/4.0/. The Creative Commons Public Domain Dedication waiver (http://creativecommons.org/publicdomain/zero/1.0/) applies to the data made available in this article, unless otherwise stated in a credit line to the data. 


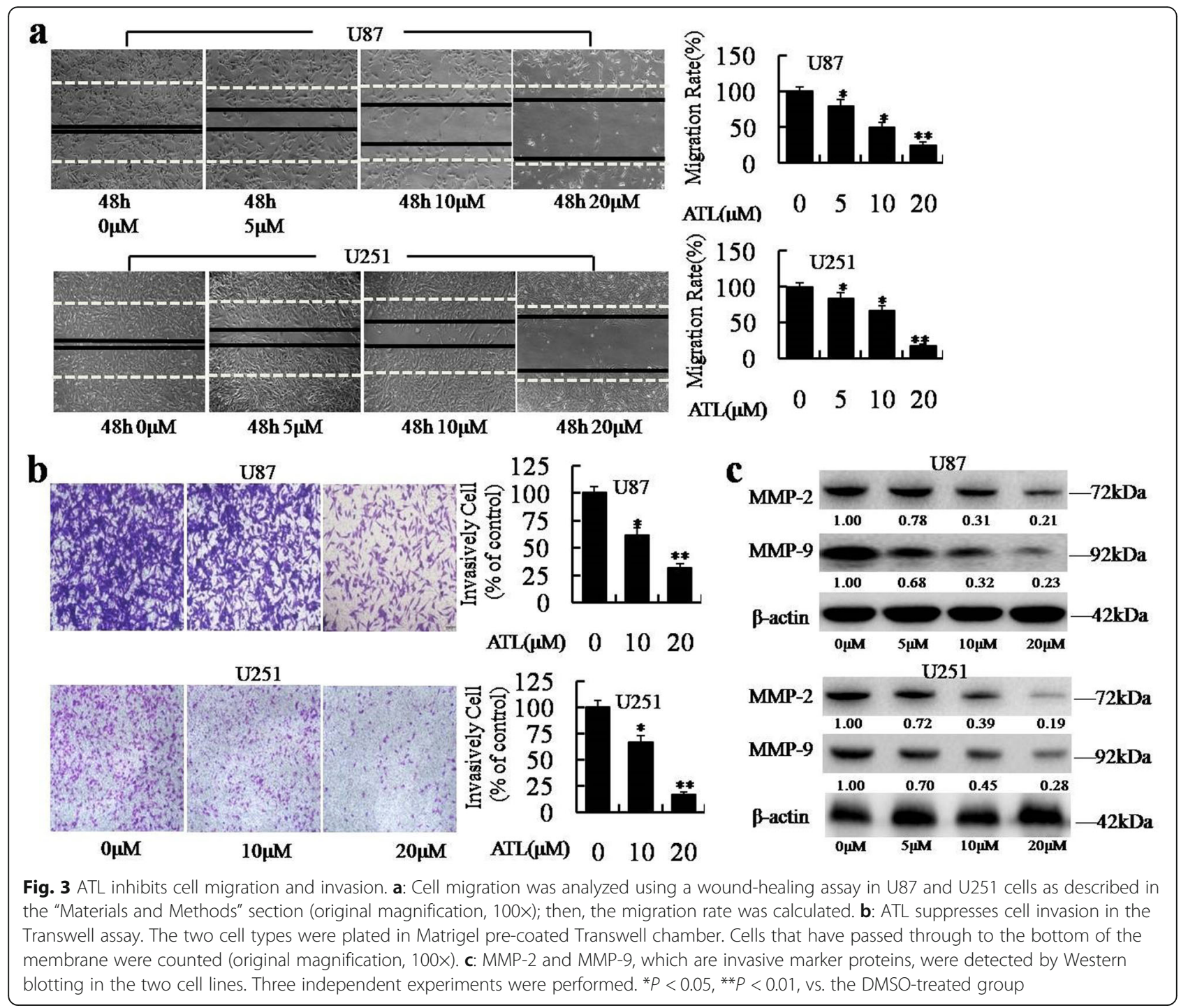




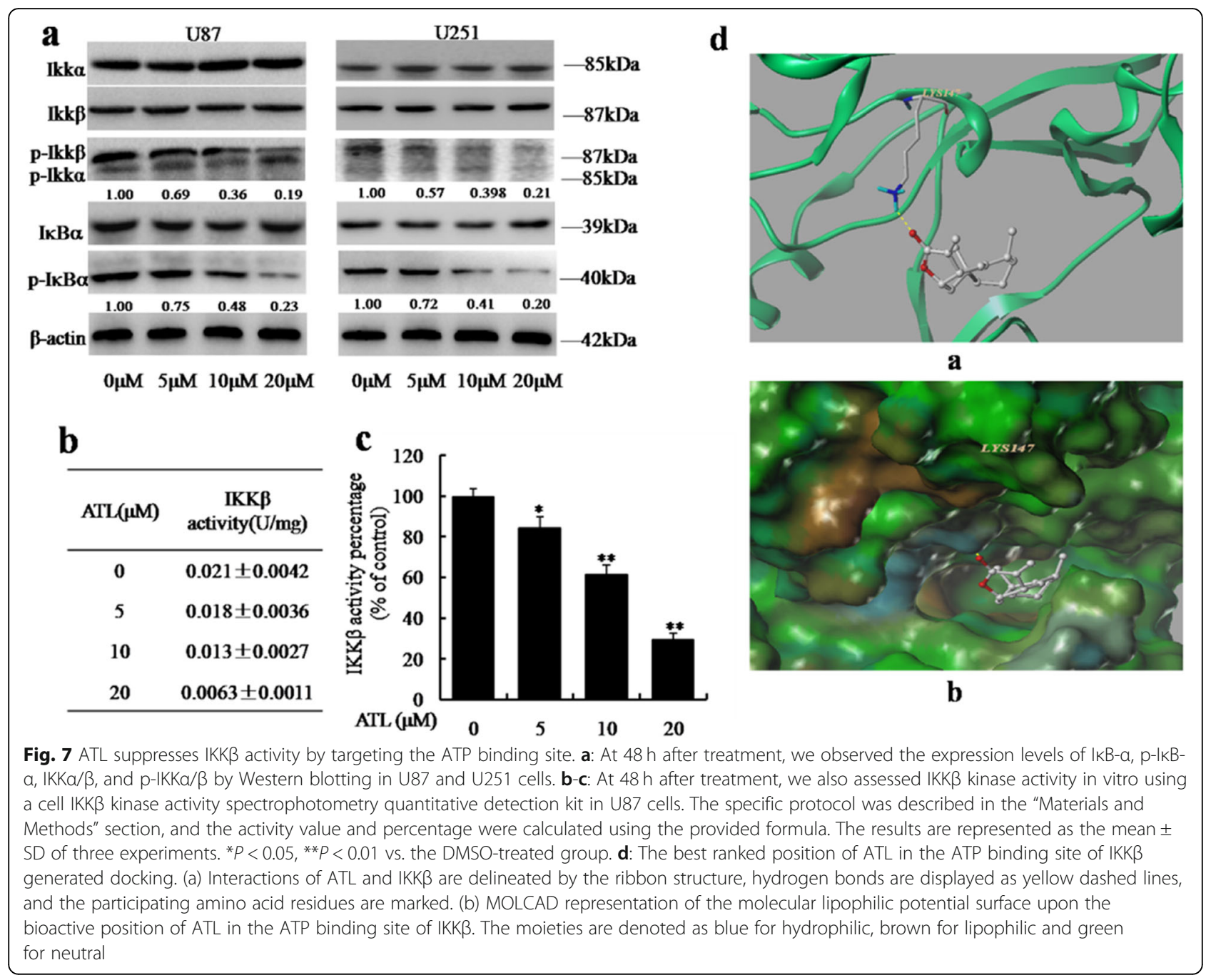

